\title{
Erratum to "Propolis Inhibits Neurite Outgrowth in Differentiating SH-SY5Y Human Neuroblastoma Cells" [Toxicol. Res. 32 (2016) 239-243]
}

\author{
Han Bit Kim and Byung Sun Yoo
}

Dept. of Life Science, Kyonggi University, Suwon, Korea

Author wanted to change the acknowledgement stating the funding source from "Funding for this paper was provided by Kyonggi University (2003)" to "Funding for this paper was provided by Kyonggi University (2013)."

Correspondence to: Byung Sun Yoo, Dept. of Life Science, Kyonggi University, San94-6, Yeongtong-gu, Suwon, Gyeonggi-do 16227, Korea

E-mail: yoobs@kgu.ac.kr

DOI of original article: http://dx.doi.org/10.5487/TR.2016.32.3.239
This is an Open-Access article distributed under the terms of the Creative Commons Attribution Non-Commercial License (http:// creativecommons.org/licenses/by-nc/3.0) which permits unrestricted non-commercial use, distribution, and reproduction in any medium, provided the original work is properly cited. 